\title{
Dynamics on the Boston Consulting Group's planning matrices
}

\author{
C.G. Robinson
}

Graduate School of Business Administration, University of the Witwatersrand, Johannesburg

Strategies based on the growth share matrix as a resource allocation tool require that broad categories of businesses are either funded, milked, or divested depending on their strategic positioning on the portfolio chart. Dynamics on the chart are important and this article explores the implications of changing positions of the businesses concerned using the growth gain matrix. The little-used technique of frontier curves, which relates growth rate to cash usage, is elucidated. Because management cannot act in a vacuum and competitive action is inevitable, a checklist for competitive profiling is provided. Competitive dynamics on the growth share matrix are explored least the unwary fall into the trap of conventional strategic thinking.

S. Afr. J. Bus. Mgmt. 1985, 16: $109-115$

Strategiee wat gebaseer is op die groei-aandeel-matriks as 'n hulpbron-toedelingsinstrument, vereis dat breë kategorieê van besighede of befonds, of gemelk, of gedivesteer word afhangend van hul strategiese posisie op die portefeuljekaart. Die dinamika van die kaart is dus belangrik en hierdie artikel ondersoek die implikasies wat veranderende posisies op die kaart vir besighede wat die groei-toename-matriks gebruik, mag inhou. Die min gebruikte tegniek van 'frontier curves', of begrensingskurwes, wat die groeisyfer in verband bring met die gebruik van kontant, word verduidelik. 'n Oorsiglys vir die konstruering van mededingende profiele word verskaf omdat daar geargumenteer word dat bestuur nie in 'n lugleegte kan funksioneer nie en omdat mededinging ' $n$ onlosmaaklike deel van bestuur is. Die mededingingsdinamiek van die groei-aandeel-matriks word verduidelik om te verhoed dat die onbehoedsame persoon in die strik van konvensionele strategiese denke trap.

S.Afr. Tydskr. Bedryfsl. 1985, 16: $109-115$

C.G. Robinson

Graduate School of Business Administration,

University of the Witwatersrand, P.O. Box 31170,

Braamfontein, 2017 Republic of South Africa

\section{Introduction}

Two other planning matrices have been developed by the Boston Consulting Group to augment the use of the growth share matrix. While the growth share matrix explores the strategic positioning of a business in an attempt to predict cash flow patterns, the other two matrices explicitly address two key issues, namely

- the growth dynamics of a business, whether gaining or losing market share, and

- the relationship between growth rate and cash usage of the businesses in the portfolio.

Use of the three techniques simultaneously, considerably enhances the signals obtained from the use of the growth share matrix in isolation. A seven-step strategic checklist for using the matrices is advocated.

\section{The growth gain matrix}

Growth gain matrices can be plotted to investigate the relative growth rate of individual businesses compared with the industry average. The business growth rate is plotted on the abscissa while the industry growth rate is plotted on the ordinate as is shown in Figure 1. Circles are plotted for

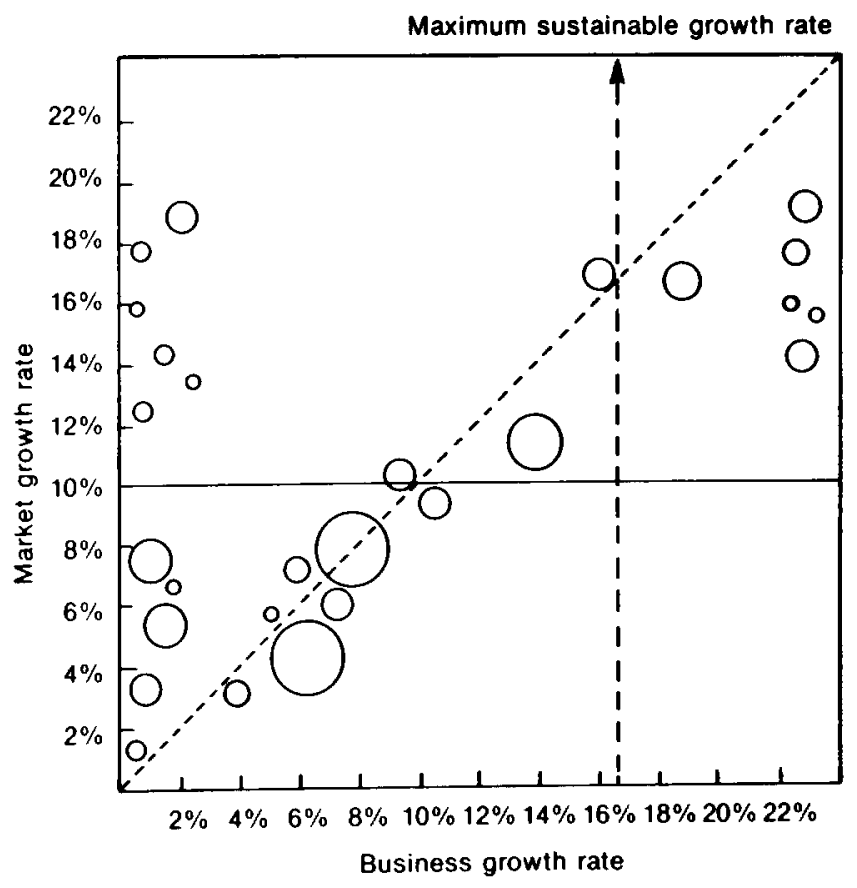


individual businesses with the areas being representative of either sales or assets invested. Businesses along the diagonal are those in which the business is growing at the same rate as the market. Businesses gaining share are located below the diagonal and those losing share are located above the diagonal. Cash cows and dogs are clustered on the lower half of the grid while wildcats and stars are in the upper half.

An idealized placing of businesses on the growth gain matrix is shown in Figure 2. Cash cows are located on the lower end of the diagonal and are simply maintaining share. Stars are located on the top of the diagonal and slightly below, increasing share slightly. Dogs are situated up against the lefthand ordinate, consistent with the decision to manage for cash at the expense of market share. Two classes of wildcats are found. The wildcats on the left-hand ordinate are being allowed to lose share and are being managed for cash. The wildcats in the upper right corner below the diagonal portray those high-growth, low-share businesses which are being funded aggressively to capture market share. Note that the portfolio shown in Figure 1 has many of the idealized characteristics.

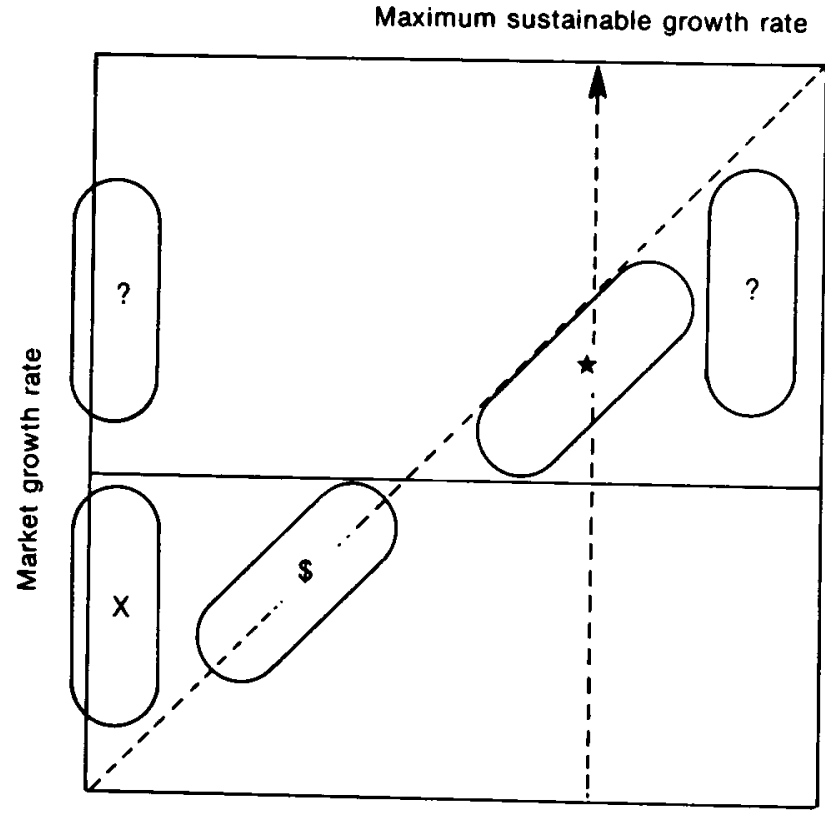

Business growth rate

Figure 2 The growth gain matrix: The ideally positioned portfolio (Hammond \& Allan, 1975:10)

The company or corporation's maximum sustainable rate of growth is given as

$g=\frac{D}{E}(r-i) p+r p$

where $g$ is the sustainable growth rate in assets, $D$ is the debt, $E$ is the equity, $r$ is the return on investment after tax, $i$ is the interest rate after tax, and $p$ is the proportion of earnings retained.

$P$ is expressed as a decimal. Debt and equity take their money values and the units for $g$ depend on those used for $r$ and $i$, percentage or decimal, as discussed before. Note that the formula gives the maximum growth rate sustainable from internally generated funds and debt leverage without recourse to the equity markets.

The maximum sustainable growth rate can be plotted as a vertical line along the business growth axis as shown in
Figures 1 and 2 . Obviously the weighted average growth rate of the businesses in the portfolio cannot exceed the maximum sustainable rate of growth without recourse to equity funds. This means the growth rate line must be the centre of gravity of the portfolio and too many of the circles cannot lie too far to the right of the maximum growth rate line. To the extent that they lie to the left an idea is given of the excess funding capacity of the portfolio. If assets had been used rather than sales on the growth gain matrix the display would give quick optical corroboration as to the feasibility or infeasibility of projected portfolios. Calculations should be used to corroborate this. Note that the calculations must include the effect of corporate overhead. This issue is discussed in the section of frontier curves.

The growth gain matrix can also be used to gain competitive insight as to where competitors are placing their emphasis provided a matrix can be drawn for the competitor.

\section{Frontier curves}

A third, though apparently seldom used, technique developed and published by the Boston Consulting Group is that of frontier curve analysis. The technique is essentially an attempt to portray the growth rate of a business in a portfolio graphcally as opposed to the cost of funding the growth in terms of the cash used (Moose \& Zakon, 1972).

The technique uses a two-dimensional grid, Figure 3 , on which the annual growth rate in profits is plotted on the ordinate and the cash use as a percentage of earnings after taxes reinvested in the business, effectively the cash use, is plotted on the abscissa. The company's major profit centres are plotted on the grid according to their growth and reinvestment characteristics over a chosen period, often five years. Businesses may fall anywhere on the grid. The location, however, is directly related to its value to the company. For example, if a business falls at a $12 \%$ growth rate and $100 \%$ cash use, the business is using all of its resources to grow at $12 \%$. The business is high growth and self financing and would be considered a star. Similarly, if a company is not increasing its annual growth rate in profits, in real terms discounted for inflation, and is only using $50 \%$ of its cash to maintain its competitive position, the remaining $50 \%$ of the cash would be available for redeployment and the company could be considered a cash cow.

In general cash cows would be expected to have profit growth rates of less than $5 \%$ and cash usage rates of $70 \%$

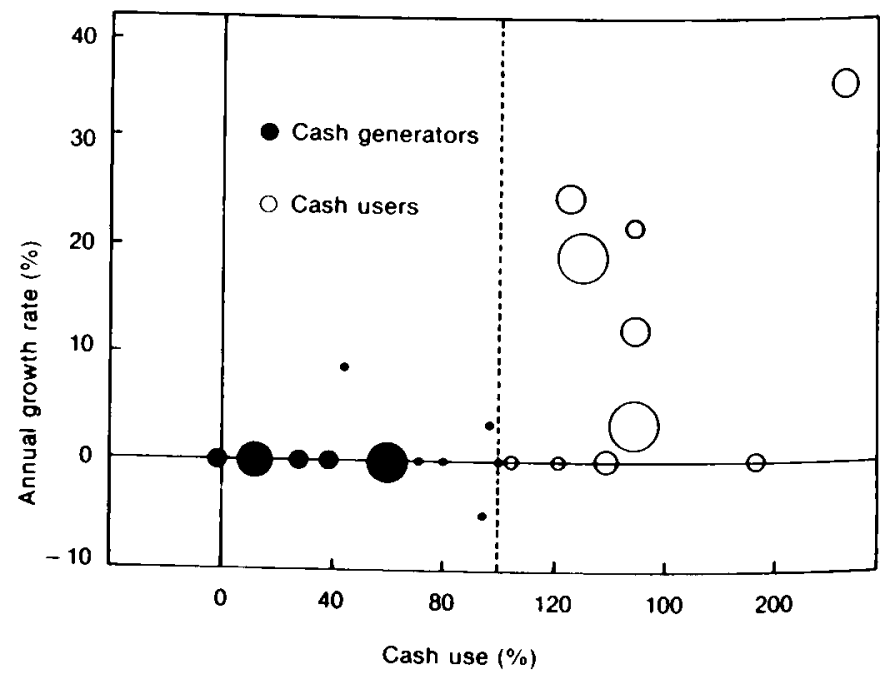

Figure 3 Frontier curves: Growth versus cash use (Moose \& Zakon, 
or less. Stars would be expected to be roughly in cash balance with growth rates in profits in excess of $10 \%$. Wildcats would be expected to have annual growth rates in profits similar to stars but higher cash usage rates. Dogs, if properly managed, should have low growth rates and be cash generators, albeit small. The theoretical positioning of the menagerie is shown in Figure 4. Businesses that don't conform to the guidelines given are probably misclassified or mismanaged and represent 'cash traps' (Moose \& Zakon, 1972:67). Plotting the businesses in the portfolio onto the grid given in Figure 4 highlights growth areas, cash generators and money traps. Thus far cash use has been understated and in reality deductions must be made for corporate cash needs in the form of dividends, interest burden, and overheads. It is assumed tacitly that the individual business, if constituted as a separate company, will have deducted dividend payments before arriving at a figure for cash use. These deductions must be made in order to arrive at a realistic appraisal. In general, most companies do not have a system for the allocation of corporate overhead, particularly concerning the thorny issue of dividend payments. The Boston Consulting Group suggests that each business be assessed on the percentage net assets employed and that the given percentage of corporate dividends, interest, and overhead be deducted from profits before per cent reinvested is calculated (Moose \& Zakon, 1972:67). Presumably the approach relates to the fact that throughout the Boston Consulting Group's analyses, the maximum sustainable growth rate of the asset base of the complete portfolio is a key issue. The approach advocated tends to reduce the number of cash generators and presumably modifies the euphoria associated with portfolio analyses conducted independently of considerations associated with corporate overhead, however burdensome and crippling it could be.

Similarly, the extent to which a corporation has a balance between cash users and cash generators cannot be determined just by the numbers of businesses falling to the left or the right of the $100 \%$ reinvestment line. The $100 \%$ cash line represents an axis about which the cash flows must be in balance, equivalent to an engineering axis with zero inertia. It is necessary to look at the relative size of the cash contributions from the cash generators and the voracity of the cash hungry. A rough approximation of the portfolio status can be given visually by marking the positions of the various businesses with circles proportional in area to the amount of cash generated or used. The larger the circle, the larger the cash use or the cash contribution. The circles tend to be larger

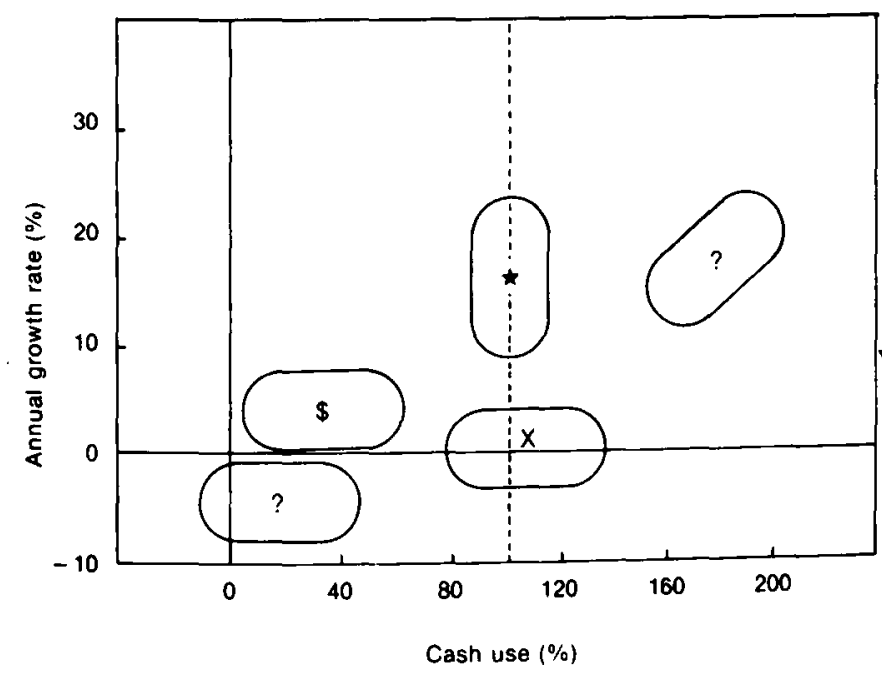

Figure 4 Idealized positions on the frontier curve at each extreme of the cash scale and reduce to pinpoints close to $100 \%$ cash use. The hatched circles in Figure 3 represent cash generators and the open circles cash users. It is possible to assess optically whether the corporation has a balance in cash terms or not. In Figure 3 the areas to the right of $100 \%$ are greater than those to the left indicating a net cash deficiency and a need for outside financing.

Figure 3 gives a guide as to the relative attractiveness of some businesses with respect to others in terms of relative growth in profits and cash flow. The concept can be extended to incorporate the concept of a goal for corporate growth. Given a corporate growth goal and assuming that the corporation invests all of its cash, a frontier line can be drawn on the grid to differentiate attractive from unattractive opportunities for the corporation.

The equation derived for the maximum sustainable internal growth rate:

$g=\frac{D}{E}(r-i) p+r p$

where $g$ is the maximum sustainable growth rate in assets, $D$ is debt, $E$ is equity, $r$ is return on net assets after tax, $i$ is interest rate after tax, and $p$ is the proportion of earnings retained, is effectively restated using the suggested method of evaluating the corporate burden involved in overheads and dividends. The Boston Consulting Group restates the equation as

$g=\frac{D}{E}(r-i)+(r-e) p$

where $e$ is an after-tax charge on assets to cover corporate overhead and dividends (Moose \& Zakon, 1972:69).

Obviously $e$ must be expressed in the dimension of $g$, that is as a percentage impact on the after-tax maximum sustainable growth rate. The equation as stated above is designed to reflect the total corporate sustainable growth rate and not that of individual businesses or products within the portfolio. The equation is a measure for discerning within the portfolio. As such it may not be necessary to calculate $e$ explicitly, as recommended by the Boston Consulting Group. The value for $e$ should be contained in $r$, the return on assets.

For given values of $D, E, r, i$ and $e$ for the corporation and provided these are held constant, equation 1 reduces to

$g=A p$ $\ldots 2$

where $A$ is a constant.

When $p=1,0$ or $100 \%$ cash retention, $g$ is equal to the sustainable maximum growth rate for the corporation - in this case the desired growth rate. The result is a series of straight lines for various targeted rates as shown in Figure 5.

The value of $A$ is easy to ascertain and, given $r, i$ and $e$, the debt equity ratio can be solved to see if it is consistent with industry norms.

The frontier curve as shown in Figure 5 allows for differentiation between businesses. Given a corporate growth goal, say 5\%, and assuming the company reinvests all of its cash, a frontier line can be drawn on the grid. Opportunities along the line are equally attractive, those below the line are less attractive and those above the line are more attractive because of their chance of higher growth with the same cash use. Under reasonable expectations the frontier line becomes a realistic investment decision line. The areas of the circles representing the chosen portfolio above and below the line can be compared to assess the cash flow characteristics of the desired portfolio. The desired corporate growth line must also 


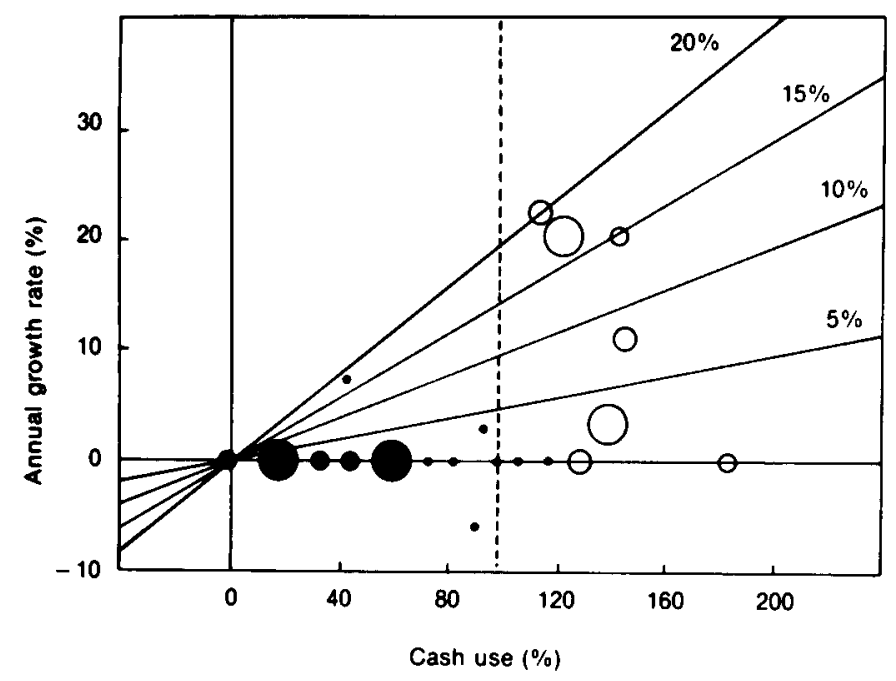

Figure 5 Frontier curves for different corporate growth targets (Moose \& Zakon, 1972:67)

be a rotational axis with a zero moment of inertia for the whole idealized portfolio.

Given that the $100 \%$ cash use line is an inertial axis as is the desired growth line, the centre of gravity of the portfolio has, both by the laws of statics and by definition, to be at the intersection of the two lines.

Up to now straight lines, rather than curves, have been used for the frontier curve. This assumes that the debt equity ratio is constant across the corporation's businesses and that all businesses, independently of their cash needs, can be leveraged to the same extent.

It can be argued that low growth businesses can be leveraged differently to high growth businesses. There also seems to be evidence that return on investment is not strongly correlated with stage of the product life cycle or the rate of growth in profits (Cvar, 1980). Because of the relative safety of low profit growth rate, mature, cash-generating businesses should support debt equity ratios greater than that of the corporate level. High growth businesses, because of their relative instability in earnings, should be less highly leveraged than the corporation as a whole.

Equation 1 can be used to generate frontier curves for different debt equity ratios as a function of cash usage patterns. The curves are found by taking the required corporate sustainable growth rate, $g$, various return and interest rates, $r$ and $i$, and varying the ratio of debt, $D$, to equity, $E$, across the range of cash usage $p$. The equation is solved for $p$. Although not stated explicitly by the Boston Consulting Group this implies being able to express $D / E$, the debt equity ratio, as a function of $p$, the cash usage rate. Curves are generated as shown in Figure 6,

It should be noted that, in addition to leverage, a small change in cash usage in a mature business tends to have a significant impact on the portfolio as a whole. A low growth business which reduces its cash use from $100 \%$ to $50 \%$ may sacrifice only one or two percentage points in growth (Moose \& Zakon, 1972:68). The same change in cash use for a high growth area may result in a disproportionate loss in growth. A retrenchment of some of the lower growth areas can be translated as a powerful switching of funds to higher growth areas.

The curvature of the curve will vary from company to company depending on the earnings trends in mature businesses and the debt equity ratios of similar competitive businesses. The Boston Consulting Group claims that the

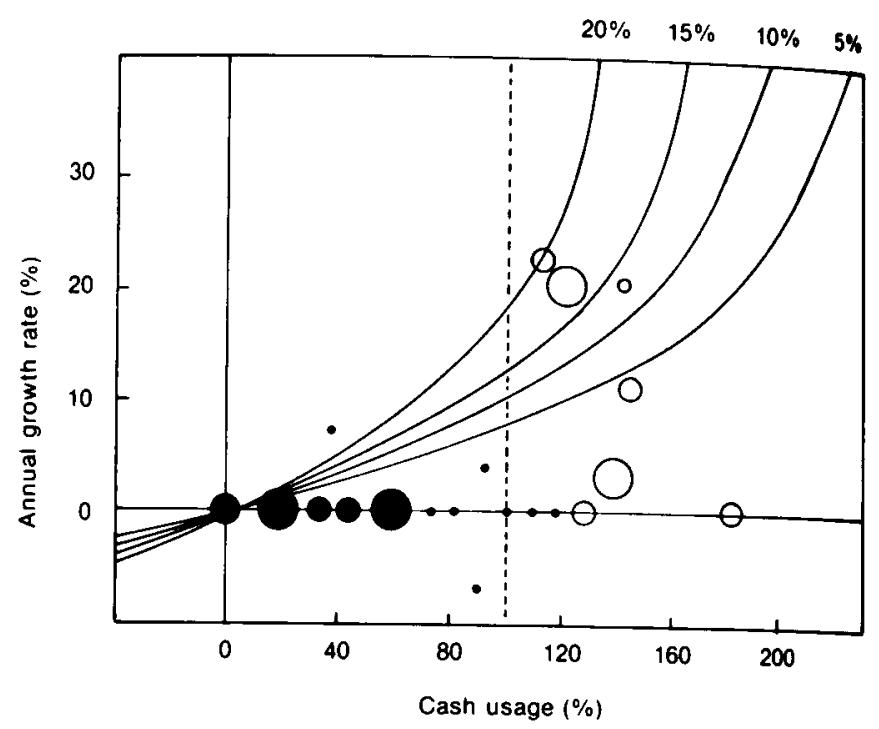

Figure 6 Frontier curves where the acceptable debt/equity ratio is negatively influenced by high growth rate (Moose \& Zakon, 1972:68)

frontier curve serves as a means of differentiating favourable investment opportunities from unfavourable areas rather broadly but in a comparable and quantifiable fashion.

\section{Competitive analysis}

Having represented the company's businesses on the growth share and the growth gain matrices, a seven-step strategic analysis should be carried out (Day, 1977:29-38 and Abell \& Hammond, 1979).

\section{Check for internal balance}

The portfolio should be examined for a reasonable distribution of the component businesses in each of the four quadrants of the growth share matrix. Products with the largest amount of sales or capital investment, as depicted by the largest circles, should appear as cash cows or stars. The majority of businesses should appear as cash cows to be used to fund and underwrite the remaining businesses. Only a few businesses should appear as question marks owing to the heavy commitment of cash and management time required to transform them into stars. Few businesses should appear as dogs as these are cash traps and require the reinvestment of the little cash they produce. Robinson (1985) illustrated the portfolio of a well-balanced, diversified company. Only a few firms achieve this kind of balance as only one business in any market can be the leader. The average company will have more products in the right-hand half of the matrix than in the left half. Ideas for improving the balance should result from the analysis.

\section{Trend analysis}

The growth share matrix tends to be a static representation of the existing status quo of the portfolio. An equivalent portfolio should be prepared for an earlier period, perhaps three to five years earlier. The two portfolios can then be superimposed upon one another to determine the direction and rate of evolution of each business. Where large changes have occurred during the elapsed time interval it may be necessary to do yearly plots to fix the velocity and direction of movement accurately (Figure 7). In companies which do yearly portfolio planning exercises the trend analysis is simplified as the latest chart only has to be compared with that of the previous year or further back if needed.

The trends can be projected for the strategic planning 


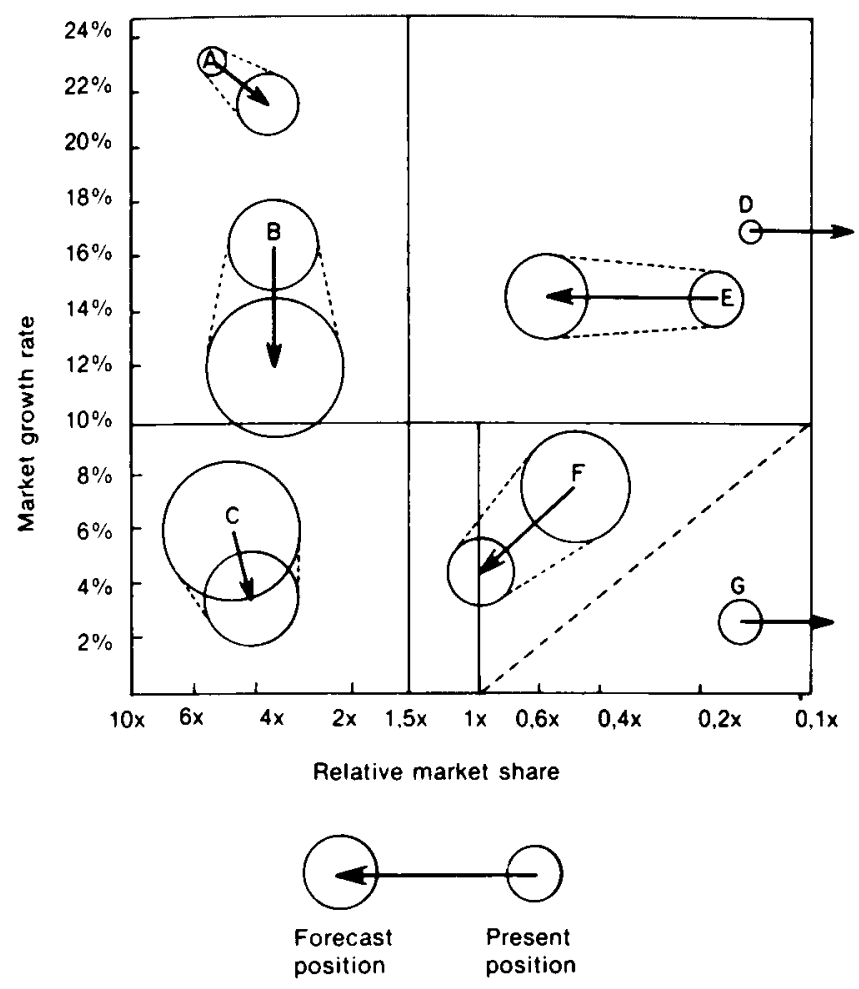

Figure 7 Portfolio dynamics: Forecasting the direction and evolution of the portfolio

period, say three to five years, to indicate where each business would be if present policies were maintained for that period. Target charts can then be developed showing the desired future position of the portfolio. Ideas for improving the evolution of the portfolio should result from this, the second stage of the analysis.

The next stage is to determine the feasibility of each plan under competitive conditions and financial constraints.

\section{Evaluate competition}

The growth share matrix and the growth gain matrix should be developed for the firm's major competitors. The displays will not be as reliable as charts for one's own firm but they should at least be a distillation of the best information available on competitors and should, as such, be more useful than the unintegrated data.

A careful analysis of the competitors' portfolios should reveal what each is doing. An analysis should give insights into their strategies and indicate their cash cows, stars, wildcats, and dogs; indicate how close they are to their sustainable growth rates; and indicate their strengths and weaknesses and where a major competitor might be so concerned with an area that he would be unlikely to mobilize the resources to hold off an attack in another area.

Taking one business at a time the charts should be compared to assess competitive strength where share increases are contemplated. Attempts to gain market share in low growth segments should be done when a business is roughly on a par with the dominant firm in terms of a relative market share, where it has a leadership edge on other strategic criteria, where strong leftward momentum is evident from the trend charts, or where competitors appear not to be investing. In general the decision should be to divest or manage for cash those businesses in the wildcat or dog sectors, particularly where competitors seem to be aggressively expanding strong competitive products. Attention should be focused on those products close to the 1,0 relative market share line and of sufficient size to warrant a battle with the market leader, upon question marks with sufficient leftward momentum and upon products with leadership positions.

Businesses become separated tentatively into four basic strategic sets:

- Growth businesses earmarked for market share growth,

- maintenance businesses,

- harvesting candidates to be milked for maximum cash flow, and

- divestment candidates.

In addition the impact of strategic pricing decisions can also be made particularly with regard to the interplay between one's own portfolio and that of competitors. Two examples are graphically portrayed in Figures 8 and 9.

In Figure 8 the firm has three business units, one a largish star, A, a dog, B, and a cash cow, C. The main opponent also has a substantial wildcat, $\mathbf{A}^{\prime}$, and a large cash cow, $\mathbf{B}^{\prime}$. Conventional strategic planning would advocate that: .

- the star, A, be funded, if needed,

- the dog, B, be divested or gradually run down, and

- the cash cow, C, be used to fund $A$.

This, however, leaves the way right open for the competitor to use his substantial cash flow from his cash cow, B', to fund his wildcat, $A^{\prime}$, into star status. Potential exists for predatory price cutting by the dog B in competition with $\mathrm{B}^{\prime}$ designed to upset the cash flows from $B^{\prime}$ and prevent the funding of $\mathbf{A}^{\prime}$ in competition with $\mathbf{A}$.

In Figure 9 a conscious decision has been made to raise prices and margins on the cash cow, $\mathrm{C}$, in order to maximize

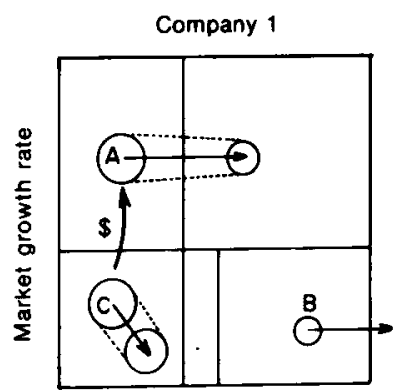

Relative markel share

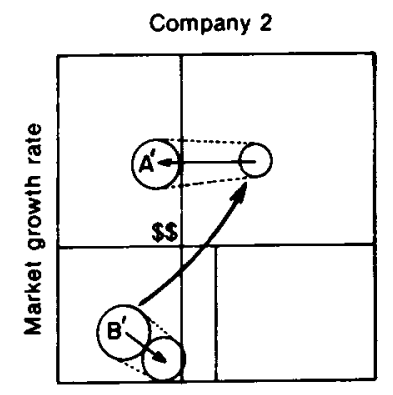

Relative market share
Conventional logic: Company 1 uses cash cow $C$ to fund $A$ insufficiently and divests itself of $B$ Compary 2 uses cash cow $B^{\prime}$ to fund $A^{\prime}$ and overtake business $A$ of company 1.

Figure 8 Competitive dynamics on the growth share matrix

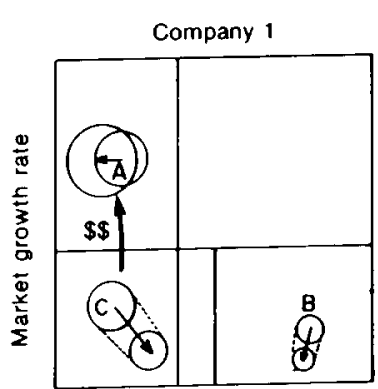

Relative market share

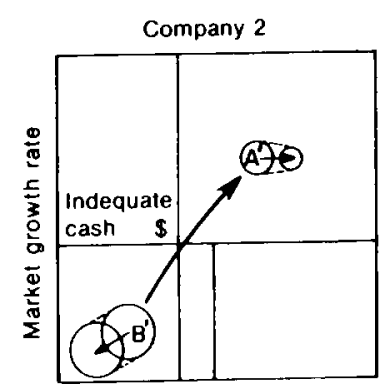

Relative market share
Competitive logic: Company 1 uses cash cow $C$ to fund $A$ Company 1 discounts in business $B$ to upset company 2 Company 2 engages in price war with cash cow $B^{\prime}$ and funds for A dry up prejuducing A's competitive position.

Figure 9 Competitive dynamics on the growth share matrix 
its cash flow in spite of a drift owing to loss of market share. The enhanced cash flow is designated for use in funding a large wildcat, A, into a dominant position over the competitor's business. Competitive pricing by the dog B, has had the effect of decreasing the competitor's cash flow from B' owing to predatory price cutting and has eroded his ability to finance $A^{\prime}$.

Sound competitive analysis coupled with creativity in assessing the strategic implications of moves which would upset the competition is crucial for strategy development. It is often the weakest link. It is often seen to be both difficult and highly speculative. Many analysts prefer the easier analysis of internal data. Strategic nirvana, however, is not likely to be reached by introspective contemplation of one's own navel. Problems associated with lack of data must often be overcome by imaginative use of data sources.

\section{Consideration of other factors}

The portfolio display is concerned with a measure of market attractiveness as expressed by market growth rate and competitive ability as expressed by relative market share. The location of businesses on the chart indicates their cash characteristics. The area of the circle representing a business portrays the relative sales or investment associated with the business. Properly employed, this information is a substantial input to the planning process.

Additional information must be weighed prior to deciding on strategies for each business and on the implementation details of each strategy (Day, 1977 and Abell \& Hammond, 1979). Consideration also needs to be given to the acceptance of suboptimal performance to ensure the availability of critical inputs and the need for criteria such as cash flow and profit volatility to be restrained. A detailed discussion follows later.

\section{Industry position}

The growth share matrix uses market growth rate and relative market share as surrogate variables to indicate the cash flow requirements of the portfolio. The analysis can be further refined by plotting the growth gain matrix relating market growth rate to the growth rate of the business under consideration (Figure 1). Products above the diagonal represent market growth in excess of product growth, indicating declining market share. Ideally only businesses being milked, divested, or phased out and businesses due to receive major efforts to gain market share should lie above the diagonal. If this is not the case then the strategic classifications established in phase 3 should be revised to account for it.

The analysis of industry position should corroborate the trend analysis of step 2 in a graphic manner. Plotting the maximum sustainable growth rate of the portfolio on the vertical axis allows for the selection of business strategies to improve their position relative to the idealized patterns shown on Figure 2. For example a dog due for harvesting which is positioned near the maximum growth rate line can be repositioned near the ideal zero growth axis by allowing market share to decline in order to maximize cash flow.

\section{Develop possible target portfolios}

Target portfolios can now be developed on the strength of the previous four steps, notably checking for balance, trend analysis, evaluation of competition, a consideration of key strategic factors not covered in the portfolio approach, and an analysis of industry position. Tentative strategies for each business can be identified on the basis of their position on the matrix.

\section{Cash cows}

The usual strategy is to maintain market dominance and use the strong cash flows these businesses generate. Product, technological and price leadership is maintained. Product proliferation and investment in market expansion is guarded against to prevent the sapping of cash flow. 'Exceptions would include expansion to exploit a competitor's weaknesses and new, hard-to-copy product innovation, or increases in primary demand' (Abell \& Hammond, 1979:189). The focus is maintenance of market and cost dominance while excess cash is channeled into better opportunities.

\section{Dogs}

The closer the dog is on the spectrum toward the cash cow business quadrant, the more amenable it is to being treated as a cash cow. The lower the growth rate and the lower the relative market share, the more the dog becomes a candidate for divestment, abandonment, harvesting, or strategic market segmentation.

\section{Wildcats}

Most wildcats are in an untenable position because of the poor margins and heavy cash demands. The choices are to expand a few into stars, to focus a few others and to exit the rest. Expansion is geared to gaining a disproportionate share of the growing market or the acquestion of competitors. Dominance can be obtained in a market niche by strategic segmentation. Exiting can be via divestment as a going concern, harvesting or abandonment.

\section{Stars}

Market share is either held or grown slightly. Being almost self sufficient, cash infusions are small or infrequent. Building share in a high growth business can easily be obtained by gaining a large proportion of new market business. Holding share is achieved by price reductions, product improvements, production efficiencies and improved market coverage.

\section{Check financial balance}

Detailed pro forma cash flow calculations must be carried out to check the strategic decision chosen. Cash flow needs and generation of each strategy must be checked. Estimates of internally generated and externally available funds must be made and balanced.

If a shortage of cash is forecast, then some businesses may have to be reclassified and more dogs and question marks may need to be harvested or abandoned. Some gains in market share may have to be foregone.

An analysis of the financial balance of competitors will reveal cash flow constraints which will shape their portfolios and their anticipated actions.

\section{Conclusion}

The growth gain and frontier curve matrices provide additional insights into the dynamics of analysis and cash allocation around a portfolio. A strategic checklist can be generated to guide the planning process in an attempt to ensure that the unwary do not fall into pitfalls awaiting a too simplistic approach to portfolio planning.

\section{References}

Abell, D.F. \& Hammond, J.S. 1979. Strategic market planning Englewood Cliffs. Prentice Hall.

Cvar, M. 1980. Strategic planning: What is it? Cambridge, Massachusetts. Strategic Planning Institute. 
Day, G.S. 1977. Diagnosing the product portfolio. J. Mark. vol. 41, $29-38$.

Hammond, J.S. \& Allan, G.B. 1975. A note on the Boston Consulting Group concept of competitive analysis and corporate strategy. Boston, Massachusetts. Harvard Business
School, note 9-175-175.

Moose, S.A. \& Zakon, A.J. 1972. Frontier curve analysis: As a resource allocation guide. J. Bus. Policy, 63-70.

Robinson, C.G. 1985. The Boston Consulting Group's strategic menagerie. S. Afr. J. Bus. Mgmt., vol. 16, 76-86. 